\title{
PEMANFATAN LIMBAH SERBUK GERGAJI ULIN DAN KAYU BIASA SEBAGAI ENERGI ALTERNATIF PENGGANTI BAHAN BAKAR MINYAK
}

\author{
Dikirim tanggal 27 September 2017 Diterima 26 Desember 2017 Dipublish 27 Desember 2017 \\ Chairunnisa \\ Madrasah Aliyah Negeri 3 Banjarmasin \\ Email: nisa63ch@gmail.com
}

\begin{abstract}
ABSTRAK
Konsumsi bahan bakar di Indonesia telah melebihi produksi dalam negeri. Dalam kurun waktu 10-15 tahun ke depan cadangan rainyak bumi Indonesia diperkirakan akan habis. Oleh karena itu, usaha untuk mencari bahan bakar alternatif yang dapat diperbaharui (renewable), ramah lingkungan dan bernilai ekonomis, semakin banyak dilakukan. Limbah industri kayu dan pertanian seperti serbuk gergaji ulin dan serbuk gergaji kayu biasa yang banyak terdapat di Banjarmasin belum termanfaatkan sepenuhnya, padahal bahan-bahan tersebut merupakan biomassa dengan nilai kalor yang relatif besar. Apabila serbuk gergaji kayu ulin dan serbuk gergaji kayu biasa maupun campuran bahan-bahan tersebut diolah menjadi briket biasa maupun briket arang, maka akan menjadi sumber energi sebagai bahan bakar alternatif yang dapat terbarukan.

Proses pembuatan briket diawali dengan cara mengeringkan serbuk gergaji ulin maupun serbuk gergaji kayu biasa di bawah terik matahari untuk mengurangi kadar airnya. Untuk pembuatan briket biasa,bahan yang ingin diteliti dicampur dengan perekat lem tepung kanji, kemudian dicetak dan dikeringkan. Pembuatan briket arang dimulai dengan membakar bahan dengan pembakaran biasa. Arang yang telah terbentuk kemudian ditumbuk dan diayak dengan alat pengayak untuk mendapatkan ukuran partikel tertentu. setelah itu bahan dicampur dengan perekat lem tepung kanji, kemudian dicetak dan dikeringkan.

Telah berhasil dibuat bahan bakar energi alternatif dari briket limbah serbuk gergaji ulin yang cukup ramah lingkungan, dapat diperbarui (renewable), sederhana dan bernilai ekonomis. Hasil penelitian menunjukkkan dengan massa yang sama, briket biasa maupun briket arang yang dari serbuk gergaji ulin lebih baik dari serbuk gergaji kayu biasa, karena menunjukkkan waktu yang paling lama dan nyala api yang lebih stabil serta lebih ramah lingkungan dan dapat digunakan sebagai bahan bakar alternatif pengganti bahan bakar minyak.
\end{abstract}

Kata Kunci: Energi alternatif, Serbuk gergaji ulin

\section{PENDAHULUAN}

Sekitar 250 tahun lalu, nenek moyang kita sepenuhnya mengandalkan sumber-sumber energi alamiah. Bajak ditarik oleh hewan, kincir angin untuk menggiling jagung, kayu untuk memasak dan otot manusia sebagai sumber tenaga penggerak. Sekarang, terutama di negara maju, otot hanya menyumbang kurang dari satu persen untuk aktivitas. Sisanya, dalam kerja, memproduksi barang dan

jasa sepenuhnya disokong oleh bahan bakar fosil yang sifatnya tidak terbarukan, tetapi konsumsinya selalu meningkat dari tahun ke tahun (Prihandana., dkk, 2007). 
Konsumsi bahan bakar di Indonesia telah melebihi produksi dalam negeri. Dalam kurun waktu 10-15 tahun ke depan cadangan minyak bumi Indonesia diperkirakan akan habis. Perkiraan ini terbukti dengan seringnya terjadi kelangkaan BBM di beberapa daerah di Indonesia (Hambali, E., dkk, 2006). Kelangkaan dan kenaikan harga minyak akan terus terjadi karena sifatnya yang tidak dapat diperbaharui. Hal ini harus segera diimbangi dengan penyediaan sumber energi alternatif yang dapat diperbaharui, melimpah jumlahnya dan murah harganya sehingga terjangkau oleh masyarakat luas (Hermawan, 2006). Dari tujuan tersebut, teknologi untuk energi alternatif haruslah menerapkan metode yang hemat sumber daya, mudah dirawat, dan berdampak polusif minimalis (polusi minimal) dibandingkan dengan teknologi arus utama (bahan bakar fosil) yang pada umumnya beremisi banyak limbah dan mencemari lingkungan.

Berdasarkan permasalahan di atas, maka usaha untuk mencari bahan bakar alternatif yang dapat diperbarui (renewable), ramah lingkungan dan bernilai ekonomis, semakin banyak dilakukan contohnya briket atau briket arang. Briket adalah bahan bakar karbon dalam suatu bentuk yang variatif diproduksi dari limbah bahan organik maupun turunannya yang masih mengandung sejumlah energi. Menurut Hartoyo dan Rohadi (1978) dalam Capah (2007), briket arang adalah arang kayu yang diubah bentuk, ukuran, dan kerapatannya dengan cara mengempa campuran serbuk dengan bahan perekat. Bahan baku yang digunakan untuk pembuatan briket adalah arang kayu atau kayu yang berukuran kecil yang diperoleh limbah industri kayu penggergajian atau industri perkayuan. Tsoumis (1991), mengemukakan bahwa briket juga terbuat dari residu berkarbon dan digunakan untuk pembakaran dan kegunaan lainnya. Pada beberapa produk, bahan tambahan diperlukan, seperti lilin untuk menambah pembakaran dan substansi lainnya untuk memberi bau yang menyenangkan dan warna yang seragam. Briket arang adalah arang yang diolah lebih lanjut menjadi bentuk briket, sehingga penampilan dan kemasannya lebih menarik dan dapat digunakan untuk keperluan energi sehari-hari (Pari, 2002). Briket arang merupakan bahan bakar padat yang mengandung karbon, mempunyai nilai kalori yang tinggi, dan dapat menyala dalam waktu yang lama.

Serbuk gergaji kayu ulin dan serbuk gergaji kayu biasa belum termanfaatkan sepenuhnya, padahal bahan-bahan tersebut merupakan biomassa dengan nilai kalor yang relatif besar. Maka dari itu, penelitian ini menggunakan serbuk gergaji kayu ulin, serbuk gergaji kayu biasa maupun campuran bahan-bahan tersebut untuk diolah menjadi briket biasa maupun briket arang. Serbuk gergaji ulin dan serbuk gergaji kayu biasa yang diambil dalam penelitian ini berasal dari limbah industri kayu yang ada di kecamatan Batumandi Kabupaten Balangan yang jumlahnya banyak dan dibuang begitu saja tanpa ada pengolahan limbah secara optimal, sehingga diharapkan dengan pengolahan bahan-bahan tersebut menjadi briket membuat limbah tersebut bisa didaur ulang dan dimanfaatkan sebagai bahan bakar energi alternatif.

\section{METODE PENELITIAN}

Bahan penelitian yang digunakan adalah serbuk gergaji ulin dan serbuk gergaji kayu biasa yang diperoleh dari sisa limbah pengolahan kayu di Bansau (pabrik kayu) Banjarmasin serta lem tepung kanji dan tawas yang diperoleh dari pasar Banjarmasin. Alat yang digunakan adalah timbangan, pipa paralon, lumping dan alu, serta alat pengayak tepung.

Briket biasa dibuat dari serbuk gergaji kayu ulin, kayu biasa, dan campuran kedua jenis serbuk (200 gr) 
kering yang dicampur dengan perekat lem tepung kanji $( \pm 50 \mathrm{ml})$ yang sudah dimasak dengan air tawas. Adonan dicetak menggunakan cetakan pipa paralon dengan diameter $4 \mathrm{~cm}$ dan panjang $2 \mathrm{~cm}$ kemudian dikeringkan.

Briket arang dibuat dari sebuk gergaji kayu ulin, kayu biasa dan campuran kedua jenis serbuk yang dikeringkan dan dibakar hingga kehitaman. Tahap selanjutnya sama dengan pembuatan briket biasa.

Penelitian dilakukan dari bulan September sampai Oktober 2016 di Laboratorium MAN 3 Banjarmasin. Data yang diperoleh adalah data kualitatif berupa warna api dan data kuantitatif berupa lama nyala api. Data dibandingkan dan disimpulkan jenis briket yang baik sebagai alternatif sumber energi.

\section{HASIL DAN PEMBAHASAN}

Hasil penelitian terhadap briket biasa dapat dilihat pada Tabel 1.

Tabel 1. Pengamatan Briket Biasa

\begin{tabular}{|c|c|c|c|c|}
\hline \multirow[t]{2}{*}{ No } & \multirow[t]{2}{*}{ Bahan } & \multirow{2}{*}{$\begin{array}{c}\text { Massa } \\
\text { (gr) }\end{array}$} & \multicolumn{2}{|c|}{ Pengamatan } \\
\hline & & & $\begin{array}{l}\text { Warna } \\
\text { api }\end{array}$ & $\begin{array}{l}\text { Waktu } \\
\text { nyala } \\
\text { (menit) }\end{array}$ \\
\hline 1 & $\begin{array}{l}\text { Serbuk } \\
\text { gergaji } \\
\text { kayu ulin }\end{array}$ & 200 & $\begin{array}{l}\text { api } \\
\text { merah } \\
(+++), \\
\text { biru (+), } \\
\text { api } \\
\text { besar, } \\
\text { asap (+) }\end{array}$ & 24 \\
\hline 2 & $\begin{array}{l}\text { Serbuk } \\
\text { gergaji } \\
\text { kayu } \\
\text { biasa }\end{array}$ & 200 & $\begin{array}{l}\text { api } \\
\text { merah } \\
(+++), \\
\text { biru (+), } \\
\text { api } \\
\text { besar, } \\
\text { asap (+) }\end{array}$ & 19 \\
\hline 3 & $\begin{array}{l}\text { Serbuk } \\
\text { gergaji } \\
\text { kayu ulin } \\
+ \text { biasa }\end{array}$ & 200 & $\begin{array}{l}\text { api } \\
\text { merah } \\
(+++), \\
\text { biru }(+) \text {, } \\
\text { api } \\
\text { besar, } \\
\text { asap } \\
(++)\end{array}$ & 10 \\
\hline
\end{tabular}

Keterangan :

$(+++)$ : banyak, $(++)$ : sedang, $(+)$ : sedikit
Dari Tabel 1 terlihat, bahwa briket biasa yang dihasilkan dari serbuk gergaji ulin, menunjukkan kualitas yang terbaik, dengan massa yang sama menghasilkan nyala api yang paling lama dan lebih stabil. Kompor dengan bahan bakar briket biasa masih menghasilkan asap, karena masih mengandung unsur hirogen dan oksigen tidak hanya unsur karbon (arang). Pada Gambar 2, terlihat warna api dari briket biasa adalah merah dengan api yang dihasilkan lebih stabil dan besar.

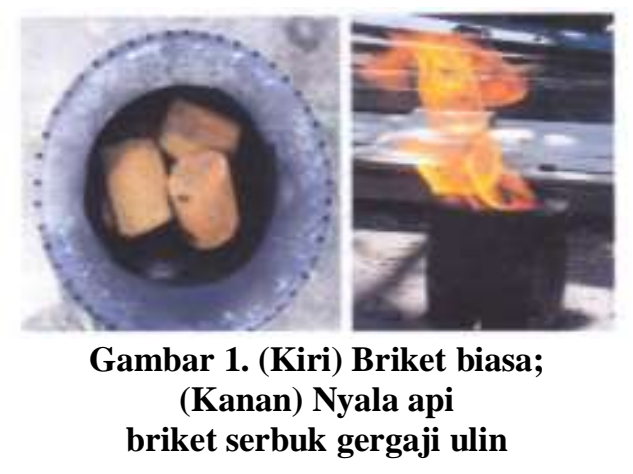

Hasil pengamatan terhadap briket arang disajikan dalam Tabel 2.

Tabel 2. Pengamatan Briket Arang

\begin{tabular}{|c|c|c|c|c|}
\hline \multirow[t]{2}{*}{ No } & \multirow[t]{2}{*}{ Bahan } & \multirow{2}{*}{$\begin{array}{c}\text { Massa } \\
(\mathrm{gr})\end{array}$} & \multicolumn{2}{|c|}{ Pengamatan } \\
\hline & & & $\begin{array}{c}\text { Warna } \\
\text { api }\end{array}$ & $\begin{array}{c}\text { Waktu } \\
\text { nyala } \\
\text { (menit) }\end{array}$ \\
\hline 1 & $\begin{array}{l}\text { Serbuk } \\
\text { gergaji } \\
\text { kayu ulin }\end{array}$ & 200 & $\begin{array}{l}\text { api } \\
\text { merah } \\
(++), \\
\text { biru } \\
(++), \text { api } \\
\text { besar, } \\
\text { asap (+) }\end{array}$ & 30 \\
\hline 2 & $\begin{array}{l}\text { Serbuk } \\
\text { gergaji } \\
\text { kayu } \\
\text { biasa }\end{array}$ & 200 & $\begin{array}{l}\text { api } \\
\text { merah } \\
(++), \\
\text { biru } \\
(++), \text { api } \\
\text { besar, } \\
\text { asap (+) }\end{array}$ & 27 \\
\hline 3 & $\begin{array}{l}\text { Serbuk } \\
\text { gergaji } \\
\text { kayu ulin } \\
+ \text { biasa }\end{array}$ & 200 & $\begin{array}{l}\text { api } \\
\text { merah } \\
(++), \\
\text { biru } \\
(++), \text { api } \\
\text { besar, } \\
\text { asap } \\
(++)\end{array}$ & 20 \\
\hline
\end{tabular}


Keterangan :

$(+++)$ : banyak, $(++)$ : sedang, $(+)$ : sedikit

Tabel 2 menunjukkan bahwa briket arang yang dihasilkan dari serbuk gergaji ulin memberikan kualitas terbaik dibandingkan dengan arang serbuk gergaji kayu biasa, maupun kombinasi arang serbuk gergaji ulin. Hal ini dikarenakan dengan massa yang sama menghasilkan nyala api yang paling lama, mempunyai asap yang paling sedikit sehingga lebih ramah lingkungan dan lebih stabil nyala api kompornya. Berat jenis serbuk gergaji ulin lebih besar dari berat jenis serbuk gergaji kayu biasa sehingga nilai kalor yang dihasilkan akan lebih besar dan dengan massa yang sama, briket arang serbuk gergaji ulin dapat menyala dalam waktu yang lama.

Secara umum, kompor berbahan bakar briket arang lebih baik dan ramah lingkungan dibandingkan dengan briket biasa karena asap yang dihasilkan lebih sedikit dan mampu menyala lebih lama dengan bahan yang sama. Hal ini karena briket arang mempunyai kandungan arang yang lebih besar jika dibandingkan briket biasa sehingga nilai kalornya (pembakaran) lebih besar dari briket biasa. Alasan ini dibuktikan dengan serbuk gergaji ulin dengan massa yang sama (200 gr), jika dibuat briket biasa nyala api berwarna merah lebih banyak, api besar, stabil selama 24 menit Sementara itu, serbuk gergaji ulin yang dibuat briket arang nyala api antara merah dan biru seimbang, api besar tetapi lebih kecil jika dibandingkan dengan nyala api briket biasa, asap yang dihasilkan lebih sedikit dan hampir tidak ada jika dibandingkan dengan asap dari briket biasa serta apinya stabil selama 30 menit (Gambar 2).
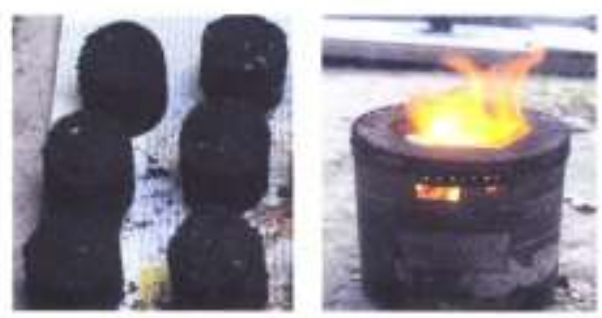

\section{Gambar 2. (Kiri) Briket arang; (Kanan) Nyala api dari arang serbuk gergaji ulin}

Dari analisis di atas, briket biasa dan briket arang yang dihasilkan dengan massa yang sama mempunyai kualitas yang berbeda, dimana briket arang menunjukkan kualitas yang lebih bagus dari briket biasa. Briket arang yang dihasilkan, selain dapat digunakan sebagai bahan bakar memasak bisa juga digunakan sebagai bahan bakar sate (pemanggang) dan lain-lain.

Keunggulan briket biasa dan briket arang dari limbah industri kayu ini antara lain :

1. Bahan bakar briket selain murah juga dapat mengurangi timbunan limbah dan sampah (mendaur ulang limbah/sampah menjadi bahan bakar alternatif);

2. Bahan-bahan pembuatan briket mudah didapat dan banyak terdapat dilingkungan;

3. Tidak tergantung pada bahan bakar di pasaran;

4. Teknologi pembuatan briket sederhana dan tidak memerlukan bahan kimia lain kecuali yang terdapat dalam bahan briket itu sendiri. Peralatan yang digunakan murah, mudah dan juga sederhana sehingga mudah pengoperasiannya;

5. Briket arang tidak mengandung unsur belerang, karena berasal dari tumbuhan yang mengandung unsur karbon, hidrogen dan oksigen;

6. Panas yang dihasilkan oleh briket biasa dan briket arang relatif lebih tinggi dibandingkan dengan kayu biasa;

7. Briket arang bila dibakar tidak terlalu menimbulkan asap maupun bau, sehingga bagi masyarakat dengan ventilasi perumahannya kurang mencukupi, sangat praktis menggunakan briket arang;

8. Setelah briket biasa dan briket arang arang terbakar (menjadi bara) tidak 
perlu dilakukan pengipasan atau diberi udara;

9. Dengan pemanfaatan limbah industri kayu menjadi briket, maka diharapkan dapat mengurangi pencemaran lingkungan, memberikan alternatif sumber bahan bakar yang dapat diperbarui dan bermanfaat untuk masyarakat;

10. Kelebihan pembentukan briket yaitu menaikan nilai kalor per unit volume, mudah disimpan dan diangkut, mempunyai ukuran dan kualitas yang seragam.

\section{PENUTUP}

yakni :

Kesimpulan dari penelitian ini

1. Limbah industri kayu serbuk gergaji ulin, serbuk gergaji kayu biasa, maupun kombinasi dari bahan-bahan tersebut dapat dibuat briket biasa maupun briket arang. Briket yang dihasilkan lebih ramah lingkungan jika dibandingkan dengan menggunakan bahan bakar kayu dan minyak tanah.

2. Briket arang yang dihasilkan mempunyai kualitas yang lebih bagus dan lebih ramah lingkungan dari briket biasa. Briket biasa dan briket arang dari serbuk gergaji ulin mempunyai kualitas briket paling bagus jika dibandingkan briket lain yang dibuat.

Karya ilmiah ini masih memerlukan pengembangan dan penelitian lebih lanjut, sehingga disarankan para pembaca baik dari siswa, guru, ataupun kalangan masyarakat agar melakukan penelitian lebih lanjut tentang

1. Pembuatan arang serbuk gergaji ulin dengan menggunakan pirolisis, yaitu pemanasan tanpa adanya oksigen pada suhu tinggi $\left(450^{\circ} \mathrm{C}-500^{\circ} \mathrm{C}\right)$, maka asap yang dihasilkan semakin berkurang.

2. Pembuatan alat cetak briket, sehingga briket yang dihasilkan lebih seragam, tidak mudah hancur/rusak dan padat.

3. Perlu penelitian lebih lanjut tentang nilai kalor yang dihasilkan masingmasing briket.

\section{DAFTAR PUSTAKA}

Capah, A.G. (2007). Pengaruh Komentrasi Perekat dan Ukuran Serbuk Terhadap Kualitas Briket Arang Dari Limbah Pembalakan Kayu Mangium (Acacia mangium Skripsi. Medan, Departemen Kehutanan, Fakultas Pertanian, Universitas Sumatera Utara.

Hambali, E., dkk. (2007). Teknologi Bioenergi Agromedia. Jakarta.

Hermawan. (2006). Pemanfaatan Limbah Sekam Padi Sebagai Bahan Bakar Dalam Bentuk Briker. Jurusan Teknik Mesin, Fakultas Teknik Universitas Jember.

Pari, G. (2002). Teknologi Alternatif Pemanfaatan Limbah Industri Pengolahan Kayu. Makalah M.K. Falsafah Sains. Program Pascasarjana.

Prihandana, K., dkk. (2007). Meraup Untung dari Jarak Pagar. Jakarta.

Tsoumis, G. (1991). Science and Technologi of Wood : Structure, Properties. 
Jurnal Tarbiyah (Jurnal Ilmiah Kependidikan)

Vol. 6 No. 2. Juli - Desember 2017 (53-57) 